\title{
Perbandingan Parameter Distribusi Butiran Hujan Arah Vertikal antara Fase Aktif dan Tidak Aktif Osilasi Madden Julian Menggunakan Metode Dual-Frequency Radar
}

\author{
Meri Yoseva, Mutya Vonnisa*, Marzuki* \\ Laboratorium Fisika Bumi, Jurusan Fisika, FMIPA, Universitas Andalas \\ Kampus Unand, Limau Manis, Padang, 25163 \\ *mutya_vonnisa14@yahoo.com, *marzuki@fmipa.unand.ac.id
}

\begin{abstract}
ABSTRAK
Distribusi ukuran butiran hujan atau raindrop size distribution (DSD) arah vertikal antara fase aktif dan tidak aktif Madden Julian oscillation (MJO) di Kototabang, Sumatera Barat, telah dibandingkan. Perbandingan dilakukan melalui parameter DSD yang dihitung menggunakan data Equatorial Atmosphere Radar (EAR) yang dikopling dengan data Boundary Layer Radar (BLR) selama proyek Coupling Processes In The Equatorial Atmosphere (CPEA)-I (10 April - 9 Mei 2004). Estimasi parameter DSD menggunakan metode dual-frequency. DSD dimodelkan dengan distribusi gamma dan parameternya didapatkan menggunakan metode momen. Dari penelitian ini terlihat bahwa intensitas curah hujan yang tinggi lebih banyak terjadi pada fase MJO tidak aktif dibandingkan dengan fase aktif. Perbedaan parameter DSD antara fase MJO aktif dan tidak aktif lebih jelas terlihat pada hujan dengan intensitas tinggi $(R \geq 20 \mathrm{~mm} / \mathrm{h})$. DSD selama fase tidak aktif mengandung lebih banyak butiran hujan berukuran besar daripada fase aktif. Hal ini ditandai dengan nilai $\Lambda$ yang lebih kecil dan $\mu$ yang lebih besar selama fase tidak aktif. Banyaknya butiran hujan yang berukuran besar ini berdampak kepada nilai radar reflectivity $(Z)$ dimana pada fase tidak aktif nilainya lebih besar dibandingkan pada fase aktif MJO. Dengan demikian, proses fisika yang menghasilkan butiran hujan yang berukuran besar dominan terjadi pada fase tidak aktif MJO.

Kata kunci: raindrop size distribution (DSD), Madden Julian oscillation (MJO), dual frekuensi, Kototabang, Equatorial Atmosphere Radar (EAR)
\end{abstract}

\section{ABSTRACT}

The vertical profile of raindrop size distribution (DSD) during active and inactive phases of Madden Julian oscillation (MJO) has been compared using the data collected by the Equatorial Atmosphere Radar (EAR) and the Boundary Layer Radar (BLR) at Kototabang, West Sumatera during the first campaign of Coupling Processes in the Equatorial Atmosphere (April 10-May 9, 2004). The DSD parameters were retrieved using a dual-frequency method. The DSD was parameterized by a modified gamma distribution and its parameter was estimated using the moment method. It was found that high rainfall intensity was more dominant during the inactive than the active MJO phases. The difference in the DSD parameter between the active and the inactive MJO phases was only significantly observed at high rainfall intensity $(R \geq 20 \mathrm{~mm} / \mathrm{h})$. The $D S D$ during the inactive phase consisted of more large size drops than those in the active phase. This can be inferred from smaller value of $\Lambda$ and larger value of $\mu$ during the inactive phase. Larger concentration of large size drops during the inactive phase led to larger radar reflectivity $(Z)$ during this phase. Thus, microphysical processes which grow large size drop are more dominant during the inactive phase than the active phase of MJO.

Keywords: raindrops size distribution (DSD), Madden Julian oscillation (MJO), dual frequency radar, Kototabang, Equatorial Atmosphere Radar (EAR)

\section{PENDAHULUAN}

Raindrop size distribution (DSD) adalah distribusi butiran hujan pada ukuran tertentu per satuan volume sampel selama interval waktu pengamatan tertentu (Jameson dan Konstinski, 2001). Distribusi DSD arah vertikal sangat penting dalam berbagai aplikasi seperti, merancang teknik remote sensing untuk pemantauan atmosfer, memprediksi atenuasi gelombang elektromagnetik yang disebabkan oleh hujan, dan mengamati hujan menggunakan radar cuaca (Kozu dkk., 2006). Selain itu, distribusi vertikal DSD juga dapat dimanfaatkan untuk memahami proses pembentukan hujan dari awal terbentuknya hingga jatuh ke permukaan tanah (Tokay dan Short, 1996).

Distribusi vertikal DSD bisa didapatkan secara langsung dengan beberapa instrumen seperti POSS (precipitation occurence sensor system) dan videosonde atau secara tidak langsung menggunakan radar atmosfer seperti radar UHF (ultra-high frequency) dan VHF 
(very-high frequency). Kedua radar ini dapat mendeteksi echo hujan dan turbulen secara bersamaan. Keduanya memiliki kekurangan, dimana radar UHF lebih sensitif terhadap echo hujan dan bisa mendapatkan secara akurat butiran hujan yang lebih kecil dari 0,5 $\mathrm{mm}$ namun kurang sensitif terhadap echo turbulen (Rajopadhyaya dkk., 1999). Di sisi lain, radar VHF sangat sensitif terhadap echo turbulen namun tidak bisa mendapatkan ukuran butiran hujan yang lebih kecil dari $1 \mathrm{~mm}$ tetapi pada saat intensitas hujan tinggi spektrum turbulen hampir tidak ada (Schafer dkk., 2002). Oleh karena itu, supaya diperoleh distribusi vertikal butiran hujan yang lebih akurat maka dapat digunakan kombinasi radar UHF dengan VHF atau dikenal dengan metode dual-frequency radar.

Penelitian ini akan menghitung parameter distribusi butiran hujan arah vertikal di Kototabang menggunakan metode dual-frequency. Radar VHF yang digunakan adalah EAR dengan frekuensi $47 \mathrm{MHz}$ dan radar UHF yang digunakan adalah BLR dengan frekuensi 1,3 GHz. Metode dual-frequency untuk kedua radar ini telah dikembangkan oleh Vonnisa dkk., (2014). Dalam penelitian ini akan dibandingkan parameter DSD selama fase aktif dan tidak aktif Madden Julian Oscillation (MJO). MJO merupakan gangguan atmosfer berskala global di atas ekuator yang bergerak dari Barat ke Timur dengan durasi 30-60 hari sehingga digolongkan variasi intra-musiman (intraseasonal variation) (Madden dan Julian, 1971). DSD dipengaruhi oleh berbagai faktor seperti lokasi, waktu dan tipe hujan (Ulbrich, 1983), variasi diurnal (Marzuki dkk., 2009), monsun (Kozu dkk., 2006) serta MJO (Marzuki dkk., 2010;2016). Namun, penelitian mengenai dampak MJO terhadap DSD masih sangat sedikit.

\section{METODE}

\subsection{Data Penelitian}

Data yang digunakan dalam penelitian ini adalah data mentah (raw data) dari EAR dan BLR yang terdiri dari echo turbulen dan echo hujan selama CPEA-I yaitu pada 10 Maret - 9 Mei 2004. CPEA-I adalah sebuah proyek penelitian yang dimulai di Jepang untuk memahami proses-proses dasar yang terjadi di atmosfer dan ionosfer di daerah ekuator.

\subsection{Pengolahan data}

\subsubsection{Pemodelan Spektrum Turbulen dan Hujan}

Untuk memperoleh DSD, diperlukan spektrum hujan dan turbulen. Spektrum hujan dimodelkan dengan persamaan (Sato dkk., 1990):

$$
S_{p}(v)=C N(D) D^{6}\left|\frac{d[v(D)]}{d D}\right|^{-1}
$$

dimana $C$ adalah konstanta dari sistem radar, $N(D)$ adalah DSD, $v(D)$ adalah kecepatan jatuh butiran, $\rho$ adalah densitas atmosfer di ketinggian tertentu dan $\rho_{o}$ adalah densitas atmosfer di atas permukaan laut. Fungsi Gauss digunakan untuk memodelkan spektrum turbulen sebagaimana digunakan oleh Sato dkk. (1990). Pada penelitian dual-frequency ini, doppler spektrum turbulen atmosfir didapatkan dari EAR dan spektrum hujan dari BLR. EAR dan BLR memiliki beam yang berbeda maka harus dilakukan koreksi lebar beam (beam broadening correction) mengikuti metode yang dikembangkan oleh Vonnisa dkk. (2014).

\subsubsection{Non-Linear Least Square Fitting dan Pemodelan DSD}

Setelah didapatkan spektrum turbulen dari EAR dan spektrum hujan dari BLR maka dilakukan proses non-linear least-square fitting dalam hal ini menggunakan metoda LevenbergMarquardt. Model DSD yang digunakan pada penelitian ini adalah model distribusi gamma yaitu dengan persamaan sebagai berikut :

$$
N(D)=N_{0} D^{\mu} e^{\Lambda D}
$$

dimana $N(D)$ adalah DSD, $D$ adalah diameter butiran, $N_{0}$ adalah intercept, $\Lambda$ adalah slope dan $\mu$ adalah parameter bentuk. 

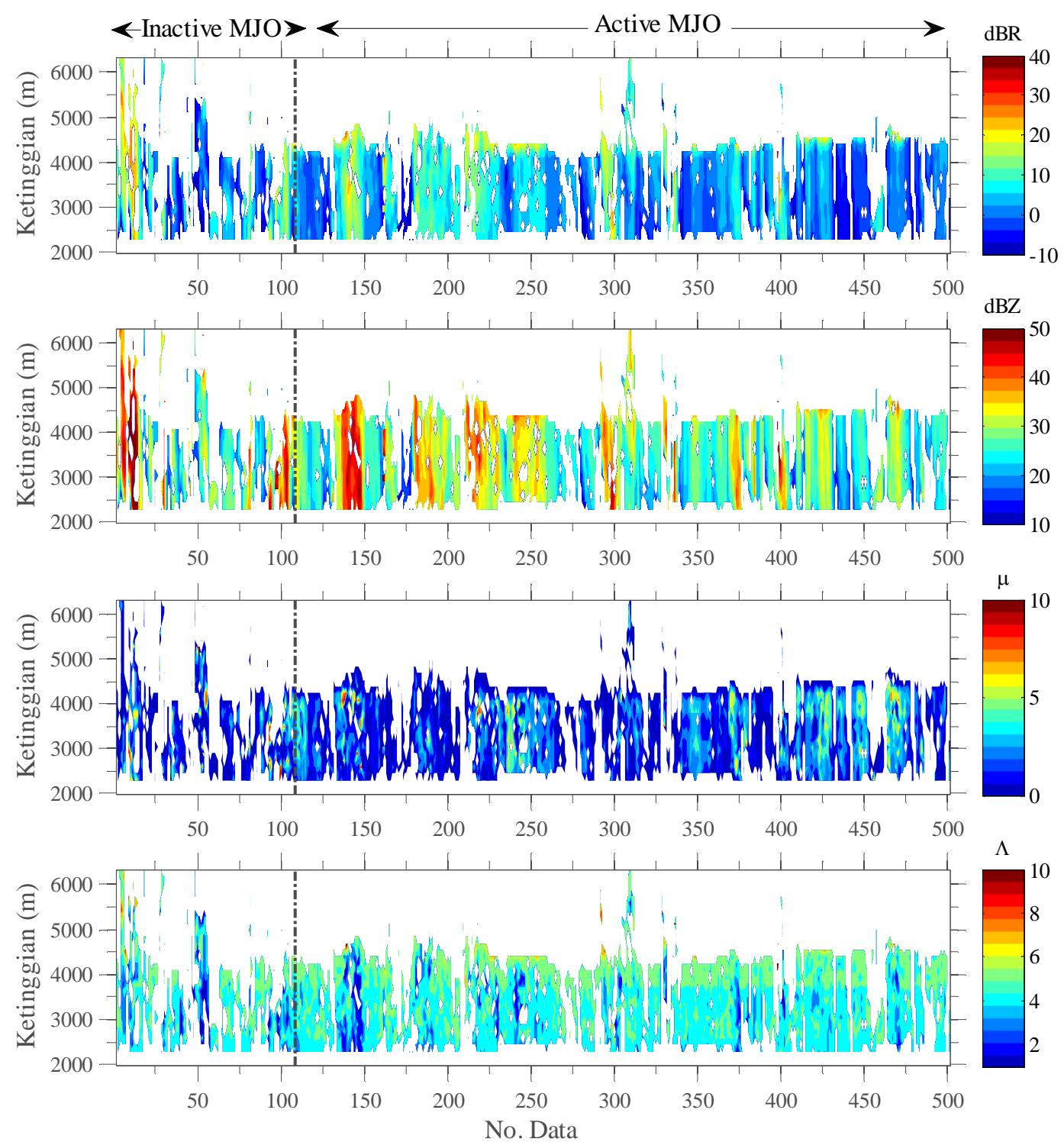

Gambar 1 Time series nilai $Z, R$ dalam skala $\log$ (a dan b), parameter $\mu$ (c) dan $\Lambda$ (d) terhadap ketinggian pada fase aktif dan tidak aktif MJO selama CPEA-I. Garis vertikal putusputus menandakan batas antara fase aktif dan tidak aktif

Persamaan (3) dapat dimodifikasi menjadi bentuk lain dengan menggunakan momen ke-x dari DSD $\left(M_{x}\right)$ yang diberikan oleh persamaan:

$$
M_{x}=N_{o} \frac{\Gamma(\mu+x+1)}{\Lambda^{\mu+x+1}}
$$

dimana $\Gamma(\mu+x+1)$ adalah fungsi gamma. Menggunakan Persamaan (3), Persamaan (2) dapat ditulis sebagai berikut:

$$
N(D)=m_{y} \Lambda_{x y}^{x+y+1} D^{\mu} e^{-\Lambda_{x y} D}
$$

dimana $m_{y}=M_{y} / \Gamma(\mu+y+1)$ dan $\Lambda_{x y}=(m x / m y)^{1 /(y-x)}, \mathrm{x}=3.67$ dan $\mathrm{y}=6$. Parameter DSD digambarkan oleh $m_{y}, \Lambda_{x y}$, dan $\mu$. $\Lambda_{x y}$ menunjukkan parameter skala $\Lambda$ yang diperoleh dari $M_{x}$ dan $M_{y}$. Persamaan (4) didapatkan berdasarkan spektrum doppler yang sebanding dengan $D^{6}|d v(D) / d D|^{-1}$ dimana $v(D)$ adalah kecepatan terminal. 


\section{HASIL DAN DISKUSI}

\subsection{Karakteristik Umum Parameter Hujan dan DSD}

Gambar 1a dan Gambar 1b memperlihatkan time series dari radar reflectivity (dBZ) dan intensitas curah hujan (dBR) untuk ketinggian dari $1990 \mathrm{~m}$ hingga $6340 \mathrm{~m}$ selama CPEA-I (10 April - 09 Mei 2004). Garis putus-putus arah vertikal menandakan batas antara fase aktif dan tidak aktif MJO. Fase tidak aktif terjadi pada tanggal 10 April hingga 22 April dan fase aktif MJO terjadi dari tanggal 23 April hingga 09 Mei.
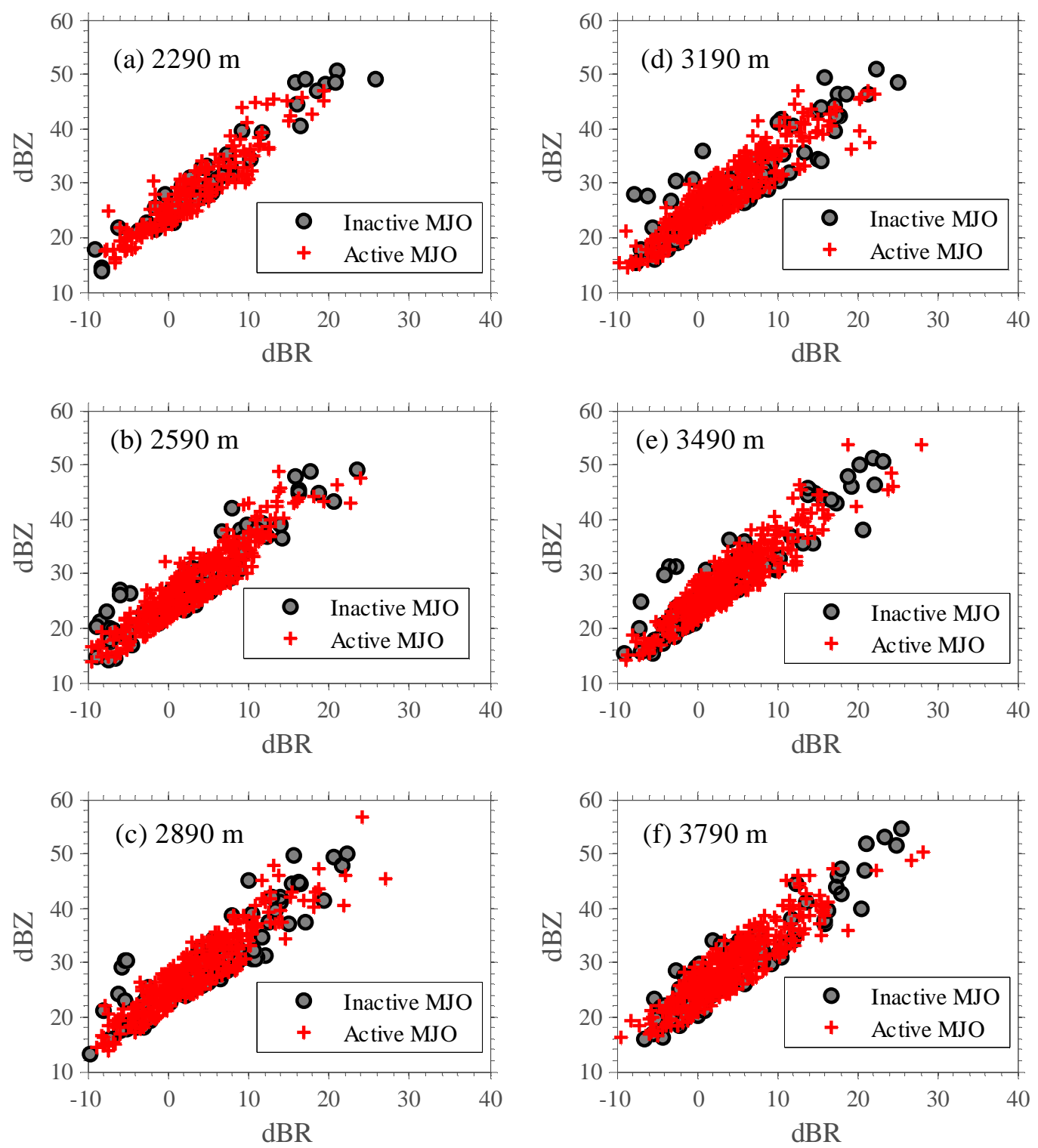

Gambar 2 Scatterplot antara dBZ dan dBR pada beberapa ketinggian untuk fase tidak aktif dan aktif MJO selama CPEA-I.

Total data pengamatan secara simultan antara BLR dan EAR selama CPEA-I adalah 501 dimana 109 data berasal dari fase tidak aktif dan 392 data dari fase aktif. Dengan demikian, hujan lebih banyak terjadi pada fase MJO aktif daripada fase tidak aktif. Hal ini konsisten dengan penelitian sebelumnya mengenai dampak MJO terhadap curah hujan di Indonesia (Marzuki, dkk., 2010; 2016). Selama fase aktif, hujan sebagian besar terjadi pada tanggal 23 April (140 data) dan tanggal 24 April (77 data). Periode ini merupakan fase awal dari MJO aktif yang ditandai dengan pergerakan Super Cloud Clusters (SCC) pertama di atas Sumatera (Shibagaki dkk., 2006; Marzuki dkk., 2010). Hujan pada fase awal MJO aktif ini terbentuk dari ketinggian yang lebih tinggi daripada periode aktif lainnya (Gambar 1a dan 
Gambar 1b). Kondisi ini terlihat jelas pada tanggal 24 April pukul 19:34-19:45 WIB (data ke 308-311). Hal ini disebabkan oleh awan hujan dari SCC pertama memiliki pergerakan udara vertikal yang lebih kuat dibandingkan dengan periode SCC lainnya (Mori dkk., 2006).

Rasio jumlah data hujan antara fase MJO tidak aktif dan aktif yang didapatkan di dalam penelitian ini adalah sekitar 1:3,6 konsisten dengan hasil Marzuki dkk. (2010) yang berdasarkan pada data curah hujan permukaan. Namun, jumlah data yang didapatkan dalam penelitian ini (501) lebih kecil dari yang didapatkan oleh Marzuki dkk. (2010) yaitu sekitar 1140 data. Perbedaan ini disebabkan oleh perbedaan sensitivitas instrumen yang digunakan. Sebagian data yang digunakan oleh Marzuki dkk. (2010), terutama hujan dengan intensitas yang rendah tidak terdeteksi oleh EAR.

Gambar 1c dan Gambar 1d memperlihatkan parameter bentuk $(\mu)$ dan slope $(\Lambda)$ dari DSD yang dimodelkan dengan distribusi gamma. Secara umum, pola terbentuknya nilai $\mu$ belum terlihat signifikan dimana perubahan nilai $\mu$ terhadap ketinggian tidak teramati dengan jelas (Gambar 1c). Namun, untuk nilai $\Lambda$ terlihat adanya sebuah kecenderungan terhadap penurunan ketinggian dimana nilai $\Lambda$ cenderung semakin kecil dengan penurunan ketinggian. Hal ini mengindikasikan bahwa terjadi peningkatan jumlah butiran yang berukuran besar dan penurunan jumlah butiran yang berukuran kecil dengan penurunan ketinggian. Pola ini sesuai dengan teori umum mengenai evolusi butiran hujan. Dalam perjalanan menuju ke tanah, butiran hujan akan mengalami peningkatan ukuran dan penurunan jumlah. Peningkatan ukuran bisa disebabkan oleh hambatan udara atau akibat proses tumbukan yang menyebabkan terjadinya penggabungan butiran-butiran yang kecil. Proses penggabungan ini akan meningkatkan jumlah butiran yang besar tetapi akan menurunkan jumlah butiran yang kecil. Penurunan jumlah butiran yang kecil dapat juga disebabkan oleh proses penguapan (Rosenfeld dan Ulbrich, 2003). Proses fisika inilah secara umum yang menyebabkan penurunan nilai $A$ dengan penurunan ketinggian.

Perbedaan parameter DSD antara fase MJO aktif dan tidak aktif menggunakan time series pada Gambar 1c dan Gambar 1d belum terlihat jelas. Oleh karena itu, untuk melihat perbedaan parameter DSD antara kedua fase ini maka dibuat plot $\mathrm{dBZ}, \mu$, dan $\Lambda$ terhadap intensitas curah hujan (dBR) untuk beberapa ketinggian (Gambar 2). Melalui plot ini kita dapat membandingkan semua parameter untuk intensitas curah hujan dan ketinggian yang sama. Ketinggian yang diambil adalah 2290, 2590, 3190, 3490, dan $3790 \mathrm{~m}$. Di atas $3790 \mathrm{~m}$ kemungkinan data sudah terkontaminasi oleh butiran es sehingga parameter yang didapatkan tidak murni dari butiran hujan saja (Rajopadhyaya dkk., 1999).

Terlepas dari perbedaan intensitas hujan yang terjadi, untuk intensitas hujan yang sama tidak terlihat adanya perbedaan nilai dBZ yang signifikan antara fase MJO aktif dan tidak aktif. Marzuki dkk. (2010; 2016) menemukan bahwa nilai dBZ pada fase tidak aktif lebih besar daripada fase aktif MJO, untuk intensitas hujan yang sama. Secara umum, perbedaan parameter $\mu$ dan $\Lambda$ antara fase MJO tidak aktif dan aktif untuk intensitas hujan yang sama tidak teramati dengan jelas (gambar tidak ditampilkan). Nilai $\mu$ sangat beragam antara 0 hingga 10 dan tidak terlihat adanya perbedaan yang signifikan antara fase aktif dan tidak aktif. Hal yang sama juga teramati untuk nilai $\Lambda$. Ketidakjelasan ini kemungkinan disebabkan oleh tidak adanya pemisahan data berdasarkan intensitas curah hujan. Marzuki dkk. (2010) juga tidak mengamati perbedaan parameter DSD untuk semua intensitas curah hujan. Mereka hanya menemukan perbedaan parameter DSD antara fase MJO tidak aktif dan aktif pada hujan dengan intensitas yang tinggi. Jika kita fokuskan perhatian kita pada intensitas hujan lebih besar dari $10 \mathrm{~mm} / \mathrm{h}$ (10 dBR) maka kita dapat melihat adanya perbedaan antara dBZ (Gambar 2) dan $\Lambda$ (gambar tidak ditampilkan) antara fase tidak aktif dan aktif MJO. Oleh karena itu, pada sub-bab berikutnya akan dilakukan pengelompokan data berdasarkan intensitas curah hujan sebagaimana yang dilakukan oleh Marzuki dkk. (2010).

\subsection{Data Rata-Rata Berdasarkan Intensitas Curah Hujan}

Gambar 3 memperlihatkan rata-rata nilai dBZ, $\mu$ dan $\Lambda$ untuk tiga kategori hujan mengikuti pengelompokan oleh Marzuki dkk., (2010), yaitu $R<5,5 \leq R<20 \mathrm{~mm} / \mathrm{h}$ dan $R \geq 20$ $\mathrm{mm} / \mathrm{h}$. Untuk $R<5 \mathrm{~mm} / \mathrm{h}$ didapatkan sebanyak 294 data selama fase aktif dan 54 data selama 
fase tidak aktif. Kemudian, untuk $5 \leq R<20 \mathrm{~mm} / \mathrm{h}$ diperoleh data sebanyak 75 dengan jumlah data pada fase tidak aktif 13 . Untuk $R \geq 20 \mathrm{~mm} / \mathrm{h}$ jumlah data secara keseluruhan adalah 25 dengan jumlah pada fase tidak aktif 12. Dengan demikian, jumlah data dengan intensitas hujan yang rendah jauh lebih banyak pada fase MJO aktif daripada fase tidak aktif.

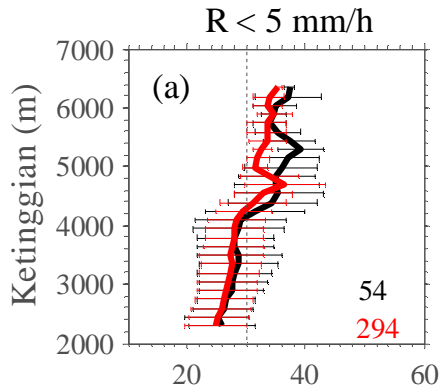

dBZ
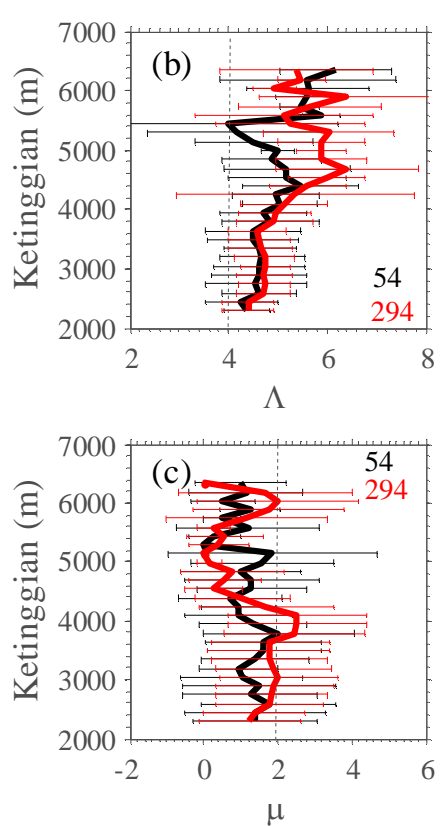

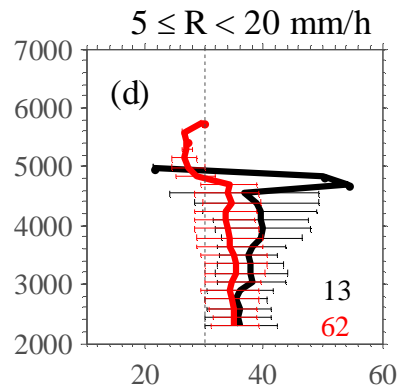

$\mathrm{dBZ}$
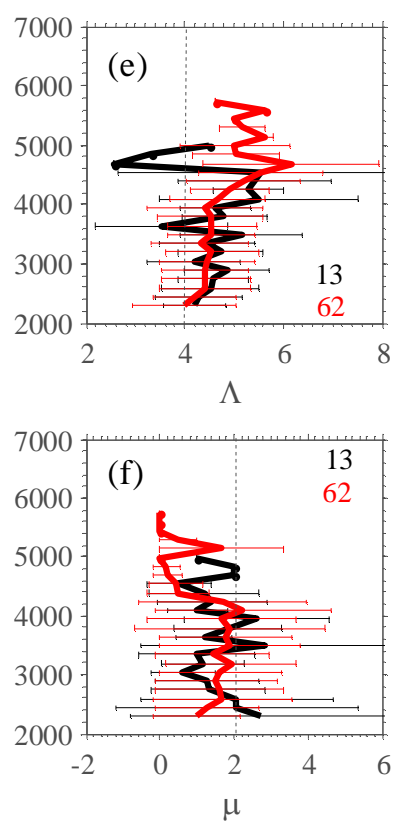

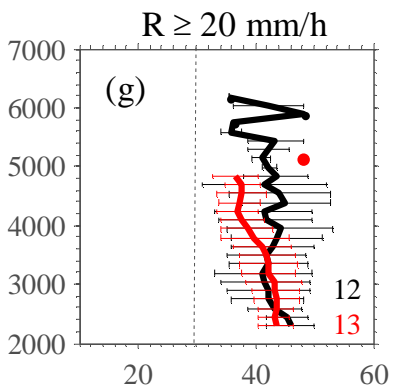

$\mathrm{dBZ}$
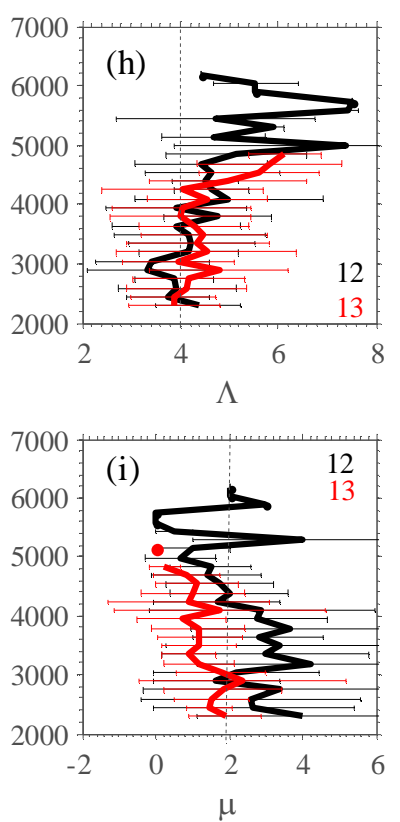

Gambar 3 Rata-rata nilai dBZ, $\Lambda, \mu$ terhadap ketinggian untuk tiga kelas intensitas curah hujan mengikuti pengelompokan oleh Marzuki dkk., (2010). Warna hitam pada grafik menunjukkan fase tidak aktif dan warna merah menunjukkan fase aktif. Jumlah data untuk setiap fase pada masing-masing intensitas curah hujan ditampilkan pada grafik. Garis horizontal memperlihatkan nilai standar deviasi dari setiap rata-rata.

Nilai dBZ memperlihatkan adanya karakteristik yang berbeda untuk setiap kagetori hujan. Untuk $R<5 \mathrm{~mm} / \mathrm{h}$, tidak terlihat perbedaan yang signifikan antara fase aktif dan tidak aktif MJO. Perbedaan semakin jelas dengan peningkatan intensitas curah hujan (Gambar 3d dan Gambar 3g). Rata-rata nilai dBZ menjadi lebih besar dengan peningkatan intensitas curah hujan. Misalnya, dBZ yang bernilai < 30 (ditunjukkan garis verikal putus-putus) sangat dominan pada $R<5 \mathrm{~mm} / \mathrm{h}$ (Gambar 3a), lebih sedikit pada $5 \leq R<20 \mathrm{~mm} / \mathrm{h}$ dan tidak ada pada $R \geq 20 \mathrm{~mm} / \mathrm{h}$. Selain itu, nilai $\mathrm{dBZ}$ memperlihatkan penurunan terhadap penurunan ketinggian (downward decreasing disingkat DD) pada $R<5 \mathrm{~mm} / \mathrm{h}$ dan agak konstan pada $5 \leq$ $R<20 \mathrm{~mm} / \mathrm{h}$ kecuali untuk fase tidak aktif dimana masih terlihat pola DD (gradien $\approx-1.88$ $\mathrm{dBZ} / \mathrm{km}$ ). Untuk $R \geq 20 \mathrm{~mm} / \mathrm{h}$, di atas $3500 \mathrm{~m}$, nilai $\mathrm{dBZ}$ pada fase tidak aktif jauh lebih besar dibandingkan dengan fase aktif yang menandakan banyak butiran hujan berukuran besar telah terbentuk pada ketinggian ini. Di bawah $3000 \mathrm{~m}$, nilai dBZ pada fase tidak aktif memperlihatkan peningkatan terhadap penurunan ketinggian (downward increasing disingkat DI) dengan gradien sekitar $6,12 \mathrm{dBZ} / \mathrm{km}$. 
Pada fase aktif, dBZ cenderung konstan dengan penurunan ketinggian (gradien DI $\approx$ $0,24 \mathrm{dBZ} / \mathrm{km}$ ). Perbedaan gradien DI dari nilai $\mathrm{dBZ}$ menandakan perbedaan tingkat pertumbuhan butiran hujan. Gradien DI yang lebih besar pada fase tidak aktif menandakan bahwa pertumbuhan butiran hujan yang menghasilkan butiran hujan berukuran besar lebih aktif pada fase tidak aktif MJO (Kozu dkk., 2005; Marzuki dkk., 2010).

Perbedaan karakteristik butiran hujan antara fase aktif dan tidak aktif MJO juga teramati dari nilai $\mu$ dan $\Lambda$. Untuk $\Lambda$, perbedaan terlihat dengan jelas pada $R \geq 20 \mathrm{~mm} / \mathrm{h}$ (Gambar 3h) dimana nilai $\Lambda$ pada fase tidak aktif lebih kecil daripada fase aktif MJO. Hal ini mengindikasikan bahwa butiran hujan yang berukuran besar lebih banyak jumlahnya pada fase tidak aktif dibandingkan dengan fase aktif. Namun, nilai $\mu$ untuk $R \geq 20 \mathrm{~mm} / \mathrm{h}$ (Gambar 3i) lebih besar pada fase tidak aktif daripada fase aktif MJO. Pada fase aktif MJO rata-rata nilai $\mu$ $<2$ sedangkan pada fase tidak aktif $\mu>2$ (ditunjukkan garis verikal putus-putus). Jika $\mu$ dihubungkan dengan nilai $\Lambda$, maka pada fase tidak aktif MJO, DSD mengandung banyak butiran hujan yang berukuran besar dan sedikit butiran hujan yang berukuran kecil yang ditandai dengan nilai $\Lambda$ yang lebih kecil dan $\mu$ yang lebih besar daripada fase aktif.

Hasil yang dijelaskan di atas sesuai dengan kerangka teoritis fase aktif dan tidak aktif MJO. Selama fase tidak aktif MJO permukaan bumi biasanya menerima intensitas sinar matahari yang lebih tinggi sehingga proses konveksi yang terjadi lebih kuat (Kozu dkk., 2005). Proses konkveksi yang kuat akan menghasilkan jumlah petir yang lebih banyak dan hal ini teramati selama fase tidak aktif MJO (Morita dkk., 2006). Kuatnya proses konveksi menyebabkan awan pada fase tidak aktif terbentuk pada ketinggian yang lebih tinggi daripada fase aktif (Marzuki dkk., 2016). Dengan demikian, butiran hujan pada fase tidak aktif terbentuk pada ketinggian yang lebih tinggi dan melalui lintasan yang lebih panjang dibandingkan dengan fase aktif. Akibatnya, butiran hujan pada fase tidak aktif mengalami pertumbuhan yang lebih aktif daripada fase aktif sehingga butiran hujan yang berukuran besar lebih banyak jumlahnya. Banyaknya butiran hujan yang berukuran besar dapat juga disebabkan oleh updraft (pergerakan udara ke atas) akibat proses konveksi yang kuat. Updraft akan mendorong ke atas atau menahan butiran yang kecil untuk jatuh dan hanya membiarkan butiran yang berukuran besar sehingga butiran yang besar lebih banyak jumlahnya dan butiran yang kecil lebih sedikit (Rosenfeld dan Ulbrich, 2003). Di sisi lain, tingginya suhu permukaan dan atmosfir bawah pada fase tidak aktif juga dapat menyebabkan butiran hujan yang berukuran kecil mengalami penguapan sehingga jumlahnya lebih sedikit dibandingkan dengan fase aktif MJO (Kozu, dkk., 2005, Marzuki, dkk., 2010; 2016) yang tercermin dari nilai $\mu$ dan $\Lambda$.

\section{KESIMPULAN}

Hasil penelitian ini memperlihatkan adanya perbedaan intensitas curah hujan dan DSD antara fase MJO aktif dan tidak aktif. Intensitas curah hujan pada fase tidak aktif lebih tinggi dibandingkan fase aktif yang terlihat juga dari tingginya rata-rata nilai dBZ. Perbedaan parameter DSD antara fase MJO aktif dan tidak aktif hanya terlihat jelas pada hujan dengan intensitas tinggi $(R \geq 20 \mathrm{~mm} / \mathrm{h})$. DSD selama fase tidak aktif mengandung lebih banyak butiran berukuran besar dan lebih sedikit butiran berukuran kecil daripada fase aktif yang ditandai dengan nilai $\Lambda$ yang lebih kecil dan $\mu$ yang lebih besar selama fase tidak aktif. Dengan demikian, proses fisika (coalescence, evaporasi, dan updraft) yang menghasilkan butiran hujan yang berukuran besar lebih dominan pada fase MJO tidak aktif.

\section{UCAPAN TERIMA KASIH}

Terima kasih kepada Dr. Hiroyuki Hashiguchi dari Research Institute For Sustainable Humanosphere (RISH), Kyoto University, Japan yang telah mengoperasikan EAR (Equatorial Atmosphere Radar) dan BLR (Boundary Layer Radar) selama proyek CPEA-I.

\section{DAFTAR PUSTAKA}

Jameson, A. R. Dan Kostinski, A.B., 2001, What is a Raindrop Size Distribution, Bulletin of American Meteorological Society, Vol. 82, No. 6, hal. 1169- 1177. 
Kozu, T., Shimomai, T., Akramin, Z., Marzuki, Shibagaki, Y. dan Hashiguchi, H., 2005, Intraseasonal Variation of Raindrop Size Distribution at Kototabang, West Sumatra, Indonesia, Geophysical Research Letter, Vol. 32, L07803, doi: 10.1029/2004GL022340.

Kozu, T., Reddy, K., Mori, S., Thurai, M., Ong, J.T., Rao D.N., dan Shimomai, T., 2006, Seasonal and Diurnal Variations of Raindrop Size Distribution in Asian Monsoon Region, Journal of the Meteorological Society of Japan, Vol. 84A, hal. 195-209.

Madden, R.A. and Julian, P.R., 1971, Detection of a 40 - 50 Days Oscillation in the Zonal Wind in the Tropical Pasific, Journal Of The Atmospheric Sciences, Vol. 28, hal. 702702.

Marzuki, M., Kozu, T., Shimonai, T., Randeu, W.L., Hashiguchi, H., Dan Shibagaki, Y., 2009, Diurnal Variation of Rain Attenuation Obtained from Measurement of Raindrop Size Distribution in Equatorial Indonesia, IEEE Transaction on Antennas and Propagation, Vol. 57, No. 4, hal. 1191-1196.

Marzuki, Kozu, T., Shimomai, T., Randeu, W.L., Hashiguchi, H., Vonnisa, M., 2010, Raindrop size distributions of convective rain over equatorial Indonesia during the first CPEA campaign, Atmospheric Research, Vol. 96, hal. 645-655.

Marzuki, Hashiguchi, H., Kozu, T., Shimomai, T., Shibagaki, Y., dan Y. Takahashi, Y., 2016, Precipitation microstructure in different Madden-Julian Oscillation phases over Sumatra, Atmospheric Research, Vol. 168, hal. 121-138.

Mori, S., Hamada, J.I., Yamanaka, M.D., Kodama, Y.M., Kawashima, M., Shimomai, T., Shibagaki, Y., Hashiguchi, H., Sribimawati, T., 2006, Vertical wind characteristics in precipitating cloud systems over west Sumatera, Indonesia, observed with equatorial atmosphere radar: Case study of 23-24 April 2004 during the first CPEA campaign periode, Journal of the Meteorological Society of Japan, Vol. 84A, hal. 113-131.

Morita, J., Takayabu, Y.N., Shige, S., Kodama, Y., 2006, Analysis of rainfall characteristics of the Madden-Julian oscillation using TRMM satellite data, Dynamics of Atmospheres and Oceans, Vol. 42, hal. 107-126.

Rajopadhyaya, D.K. and Avery, S.K., 1999, Comparison Of Precipitation Estimation Using Single- And Dual-Frequency Wind Profilers: Simulation And Experimental Result, Journal Atmospheric and Oceanic Technology, Vol.16, hal. 165 - 173.

Rosenfeld, D. dan Ulbrich, C.W., 2003, Cloud Microphysical Properties, Processes, and Rainfall Estimation Opportunities, Meteorological Monographs, Vol. 52, hal. 237-258.

Sato, T., H. Doji, H. Iwai, and I. Kimura, 1990 : Computer processing for deriving drop-size distribution and vertical air velocities from VHF Doppler radar spectra, Radio Science, Vol. 25, hal. 961-973.

Schafer, R., Avery, S., May, P., Rajopadhyaya, D., dan Willliams, C., 2002, Estimation of Rainfall Drop Size Distributions from Dual-Frequency Wind Profiler Spectra Using Deconvolution and a Nonlinear Least Square Fitting Technique, Journal of Atmospheric and Oceanic Technology, Vol. 19, hal. 864-874.

Shibagaki, Y., Kozu, T., Shimomai, T., Mori, S., Murata, F., Fujiyoshi, Y., Hashiguchi, H., Fukao, S., 2006. Evolution of a super cloud cluster and the associated wind fields observed over the Indonesian Maritime Continent during the first CPEA campaign, Journal of the Meteorological Society of Japan, Vol. 84A, hal. 19-31.

Tokay, A. dan Short, D.A., 1996, Evidence from Tropical Raindrop Spectra of the Origin of Rain from Statiform Versus Convective Clouds, Journal Applied Meteorology, Vol. 35, hal 355- 371.

Ulbrich, C.W., 1983, Natural Variations in the Analytical Form of the Raindrop Size Distribution, Journal of Climate and Applied Meteorology, Vol. 22, hal. 1764 - 1775.

Vonnisa, M., Kozu, T., dan Shimonai, T., 2014, Pengembangan Metode Dual-Frekuensi untuk Mengamati Distribusi Vertikal Raindrop Size Distribution (DSD) di Kototabang, Jurnal Ilmu Fisika, Vol. 6, hal. 52-58. 